\title{
Distinguishing between more and less suitable bentonites for storage of high-level radioactive waste
}

\author{
S. KAUFHOLD ${ }^{1, *}$ AND R. DOHRMANN ${ }^{1,2}$ \\ ${ }^{I}$ BGR, Bundesanstalt für Geowissenschaften und Rohstoffe, Stilleweg 2, D-30655 Hannover, Germany \\ ${ }^{2}$ LBEG, Landesamt für Bergbau, Energie und Geologie, Stilleweg 2, D-30655 Hannover, Germany
}

(Received 30 June 2015; revised 28 December 2015; Guest editor: Maarten Van Geet)

\begin{abstract}
One of today's big challenges is to store safely the increasing amount of high-level radioactive waste (HLRW) in the world. In some of the concepts devised for this challenge, bentonite, a natural swelling clay, plays a key role in encasing the canisters containing the waste. The use of bentonite as a geotechnical barrier in HLRW repositories is a new venture; specifications to ensure either optimum performance or that a minimum standard is reached at least do not exist yet. The present study summarizes relevant research and discusses possible HLRW-bentonite specifications. The importance of these specifications for any given repositories has to be assessed on a case by case basis, depending on the concept being employed and any special circumstances for the individual repositories.

Ten key issues were identified which were used to discuss bentonite specifications. In some of these key issues the optimum bentonite performance depended more on processing and production (compaction) than on the bentonite type (e.g. swelling pressure and thermal conductivity). In contrast, in some of the other key issues, the type of bentonite was found to influence possible specifications: the bentonite should not alter its mineral composition or its geotechnical parameters such as the swellability. Therefore, the bentonite should contain neither soluble nor reactive phases (e.g. organic matter, pyrite, gypsum). The structural Fe content of the smectites should be small because of the lesser stability and greater reactivity of the Fe-rich bentonites. Also, a large layer-charge density of the swelling clay minerals leads to less corrosion at the iron-bentonite interface (relevant if iron canisters are used). The hydraulic conductivity and swelling pressure can be tailored by compaction of the bentonite resulting in different dry densities. From an engineering point of view, a bentonite with least dependence of the hydraulic conductivity/swelling pressure on the dry density would be best. Using a bentonite which has been investigated extensively over many years means less uncertainty compared to unknown materials.
\end{abstract}

KEYWORDS: bentonite, geotechnical barrier, high level radioactive waste, repository, specifications, smectite.

The safe disposal of HLRW is a big challenge for the nuclear energy industry. The disposal of HLRW in deep geological formations is favoured. Various concepts are under investigation with a view to isolating the HLRW for a period of up to 1 million years. In some of these concepts, bentonite, a natural

*E-mail: s.kaufhold@bgr.de

DOI: 10.1180/claymin.2016.051.2.14 swelling clay with appreciable cation exchange capacity, is suggested for use as a geotechnical barrier between the metal canister containing the waste and the host rock. As an example, Sweden and Finland are planning to locate the repository in crystalline rocks (SKB, 2010; Dohrmann et al., 2013a) and enclose the canisters in highly compacted bentonite (Fig. 1). In other concepts (e.g. Switzerland) bentonite may be applied as highly compacted pellets or granulates (Fries et al., 2008). Regardless of the differences between the various concepts, bentonite plays a role in 


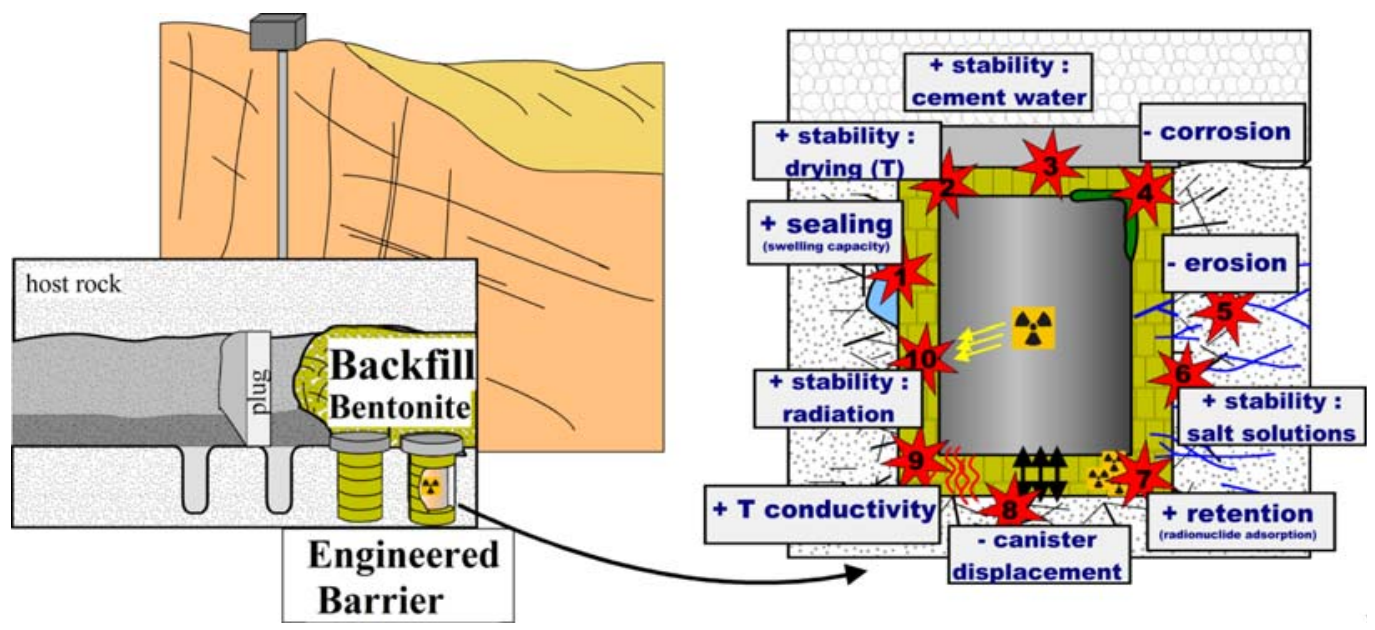

FIG. 1. Schematic representation of the planned application of bentonite as a barrier material for HLW both as backfill material and as compacted blocks directly around the canister. Specific backfill issues are not discussed here. + should be maximum (e.g. sealing); - should be minimum (e.g. corrosion).

most of them. The bentonite swelling capacity results in a low hydraulic conductivity and the ability to seal cracks even in contact with the partially fractured crystalline host rock. Bentonites are mined worldwide and their properties are highly variable. The quality of a specific bentonite is commonly determined by application tests and comparison with reference materials or standards. For example, in order to be suitable for use as cat litter, bentonite is investigated with respect to water uptake and is compared with existing products using a specific procedure. Very often a specific bentonite might be suitable for one application but not another. Thus far bentonite has not been used in the storage of HLRW because the disposal of the waste, using the methods described above, has not yet commenced in any country. Because of this lack of experience, specifications to distinguish more suitable from less suitable 'HLRW bentonites' are not yet available.

The identification of generally valid qualitydetermining parameters of HLRW bentonites is complicated by the fact that a number of different aspects have to be considered. For most established applications one main quality-determining parameter exists (e.g. viscosity for drilling fluids).

According to Sellin \& Leupin (2014) the key parameters of HLRW bentonites are low hydraulic conductivity, high self-sealing ability, and durability (stability). In order to compare bentonites these key issues needed to be specified. As an example, the stability/durability of bentonites can be modified chemically or mechanically. One additional parameter, the retention capacity for radionuclides, was added to this list of parameters. Overall, ten key issues sketched in Fig. 1 were identified and discussed in the following.

The present study focuses on bentonite in highly compacted blocks (located around the canister). The specifications for bentonites used as backfill (to seal tunnels and shafts) are not as important because of less relevant concentration gradients (of ions in porewater, $\mathrm{Fe}$ from corrosion, $\mathrm{OH}$ from cement, etc.) and temperature gradients compared to the geotechnical barrier material and the larger distance to the canister. However, a far larger amount of bentonite or other impermeable clay will be used as backfill material. The choice of the backfill material, therefore, is important with respect to the amount of components introduced into the entire repository system.

\section{BENTONITE KEY ISSUES}

The key issues summarized in Fig. 1 concern both immediate performance (e.g. issues 1 and 7) and durability (affecting long-term performance $=$ stability). In the following, an overview rather than a comprehensive review of research results concerning the different key issues is presented. For some issues minimum and maximum values are available (e.g. swelling pressure affecting sealing); for others it is difficult to present values (e.g. stability). Required and desired parameters, however, differ from one concept to another. Values are, therefore, only discussed to explain the issues or relative differences. 
Issue 1 - sealing (low hydraulic conductivity and gas permeability)

One of the most important properties of a HLRW bentonite is the sealing of possible fissures anywhere in the multicomponent system and a generally low hydraulic conductivity. The hydraulic conductivity for a relatively pure bentonite is related to the swelling pressure (Pusch et al., 2010). A minimum swelling pressure is needed to keep the canister in place and to guarantee sealing of fissures and/or cracks. Large swelling pressures also reduce the probability of microbial growth (Fru \& Athar, 2008).

Both parameters, the hydraulic conductivity and the swelling pressure, can be tailored by precompaction of the bentonite. The result of compaction, in turn, is commonly monitored by the dry density. The dry density, therefore, is taken as an indirect measure of the hydraulic conductivity and different bentonites can be compared based on their dry density-swelling pressure relation. Some published curves are shown in Fig. 2. Karnland et al. (2006) showed that the swelling pressures of the $\mathrm{Ca}$ - and $\mathrm{Na}$-forms of one bentonite differ only at low dry density $\left(<\sim 1.6 \mathrm{~cm}^{3} / \mathrm{g}\right)$. However, comparing different types of bentonites from different locations confirms the well-known variability of bentonite properties. Some of these differences can be explained by the different ways of varying the dry density (different water content or different compaction load), non-compactable porosity, and different smectite contents (Kaufhold et al., 2015b).

Bentonites with large swelling pressures despite low compaction should be better HLRW bentonites than bentonites with low swelling pressure. From an engineering point of view, however, additional aspects must be considered. On one hand, in some concepts the swelling pressure should not exceed a critical value (Sellin \& Leupin, 2014). On the other hand, an ideal bentonite should display minimum dependency of dry density on swelling pressure/ hydraulic conductivity. In other words, bentonites which provide more or less the same swelling pressure/ hydraulic conductivity both in low and dense areas are preferable because they guarantee low pressure gradients and homogeneous performance anywhere in the barrier. However, in order to identify such materials, additional research is needed, preferably at elevated ionic strength, to mimic realistic conditions. Therefore, at present, no generally valid required swelling pressure can be stated. The gas permeability should also be considered. The swelling pressure may be reduced by less compaction and thereby by increase of the hydraulic conductivity (at least partial) to provide sufficient gas permeability (if necessary). As a consequence, bentonites with low dependency of swelling pressure on compaction are advantageous. In a comparative study, bentonites compacted with 75 $\mathrm{MPa}$, which is applicable on a large scale, showed appreciable swelling pressure because the smectite content exceeded 60 wt.\% (Kaufhold et al., 2015b). Therefore, in general, recommendation of a specific bentonite with respect to the swelling pressure cannot be given at present.

\section{Issue 2 - extensive drying}

Water entering the bentonite will lead to swelling and hence to sealing. In combination with the elevated temperature of $\sim 100^{\circ} \mathrm{C}$, mineral alteration reactions may occur. In addition, the absence of water (drying) in combination with high temperatures may affect the swelling capacity of the swelling clay minerals. Greene-Kelly (1953) and Hofmann \& Klemen (1950) were the first to report on the loss of the swelling capacity upon heating. They recognized that small interlayer cations may enter the octahedral sheet at a specific critical temperature, neutralizing the permanent octahedral charge, thereby reducing the swelling capacity. However, the temperature expected in a repository will not be high enough for this process to happen. In many clay laboratories, however, clay samples are not dried above $60^{\circ} \mathrm{C}$ prior to analysis to avoid loss of swelling capacity. Kaufhold \& Dohrmann (2010) investigated a set of different bentonite powders before and after drying at $90-120^{\circ} \mathrm{C}$ for up to $4.5 \mathrm{y}$ and confirmed partial loss of swelling and cation exchange capacity (CEC). They concluded that the process of thermal reduction of swelling capacity is limited. It was also shown that within the first years of extensive drying more divalent cations were fixed than monovalent cations. The model explaining this behaviour still has to be validated. Furthermore, the degree of CEC loss at a given temperature varied among the bentonites. Those bentonites keeping more of their swelling capacity upon drying are preferable for a repository. The reason for this difference, however, is not yet understood.

\section{Issue 3 - stability against alkaline solutions}

Sealing of the canister/bentonite packages and tunnels and shafts is achieved by the use of some kind of cement in the repository. Common cement pore waters, however, are known to be alkaline and may 

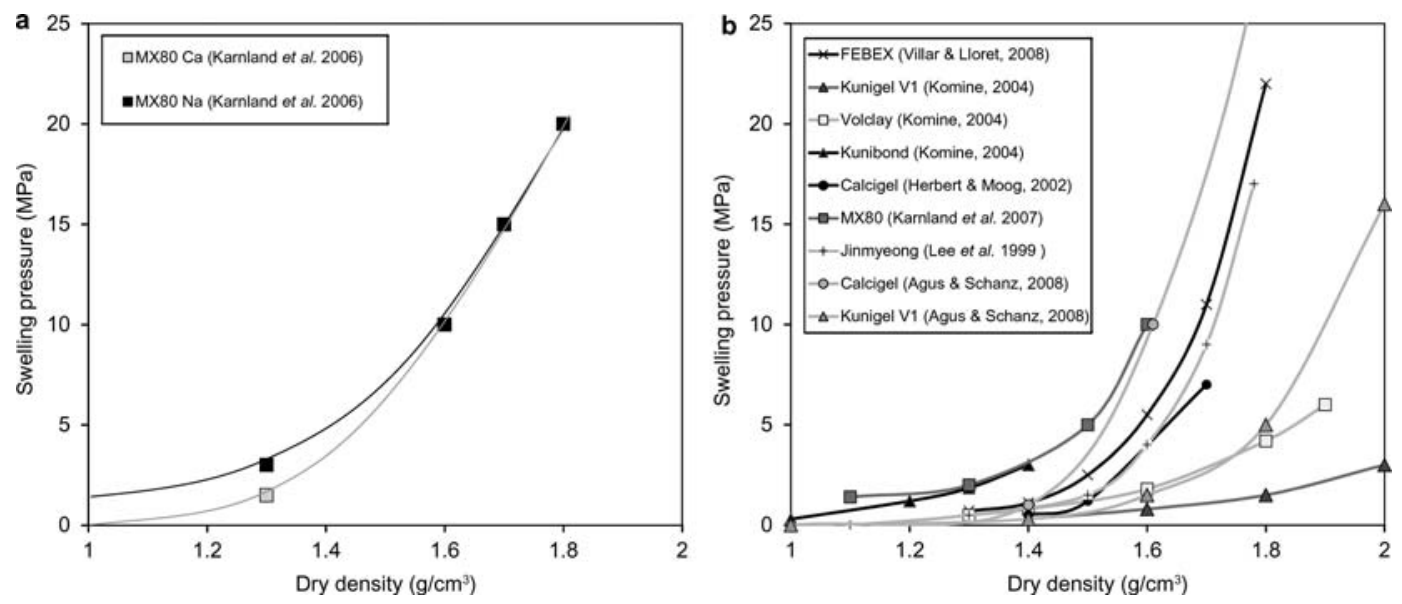

FIG. 2. Dry density/swelling pressure relations of MX80 measured in different laboratories.

alter the smectites or even other minerals. Smectite reactivity is low at $\mathrm{pH}=12$ becoming significant at $\mathrm{pH} \approx 13$ in laboratory conditions (Cuevas et al., 2007; Fernandez et al., 2010; Ramirez et al., 2002). This would be different in real systems over reaction times which are much longer than the 1 or 2 y used in laboratory tests. Nevertheless, although most studies agree about the critical $\mathrm{pH}$ values, they differ in terms of the type of alteration products which include zeolites, feldspathoids or feldspars (Fernandez et al, 2010; Savage et al., 2010) and illite or mixed-layer illite-smectite in K-bearing systems (Bauer et al., 2006).

A suitable bentonite should be as stable as possible against alkaline cement pore water. Nevertheless, for a $\mathrm{pH} \geq 13$ which pertains for at least a limited period of time in the repository (NAGRA, 1995), congruent dissolution of the swelling clay minerals and precipitation of secondary minerals will occur regardless of the type of bentonite. The type and amount of secondary minerals and the concentration of dissolved elements depends heavily on the experimental conditions including continuous or occasional shaking (batch experiments) and on the type and chemical composition of the different bentonites (Kaufhold \& Dohrmann, 2011). Therefore, a comparison of the reactivity of different bentonites in contact with highly alkaline solutions is difficult and cannot be based on the type of alteration product. However at $\mathrm{pH}=12.5$, expected in the repository (Berner, 1992), the structural elements of the swelling clay minerals are rather soluble and hence the progression of a dissolution/ precipitation reaction front will probably be determined by the $\mathrm{pH}$ buffering capacity of the bentonite towards more acidic $\mathrm{pH}$ values. In this respect $\mathrm{Ca}$-bentonites, which are generally more acidic (Kaufhold et al., 2008), are advantageous over Nabentonites (Na-activated bentonites were not considered). This property, however, may only be relevant in the very early deposition phase before the interlayer composition equilibrates with the host-rock fluid. Overall, issue 3 is less important if low-pH cements are used (e.g. Savage \& Benbow, 2007). Some additional mineralogical modifications are expected when using low-pH cement (Hatem et al., 2015). Distinguishing cement-stable from less stable bentonites is difficult because of the range of reactions

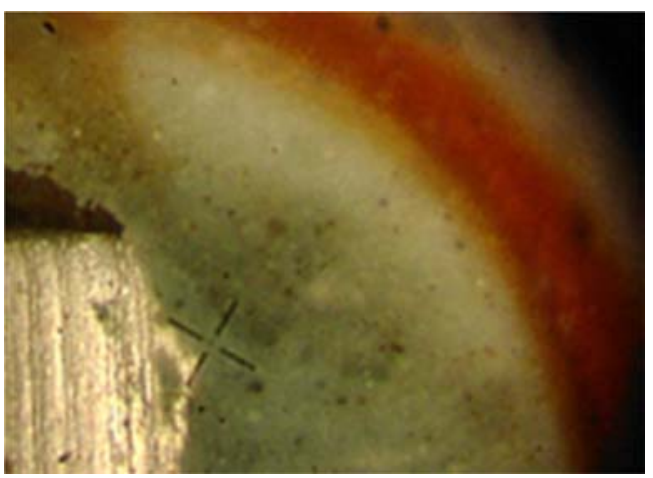

FIG. 3. Corrosion of an iron-pellet in contact with bentonite (aerobic corrosion is followed by anaerobic corrosion; image width $\approx 3 \mathrm{~cm}$; after Kaufhold et al., 2015). 
depending on the chemical composition of the bentonite.

\section{Issue 4 - stability against iron corrosion}

Some concepts use iron canisters surrounded by blocks of highly compacted bentonite (e.g. Switzerland and France). However, bentonites affect the corrosion of iron and steel (Kaufhold et al., 2015). The corrosion of iron in a HLRW repository will proceed under anaerobic conditions after the oxygen entrapped in the system has been consumed (red halo in Fig. 3). Corrosion can proceed anaerobically in spite of the fact that the exposition test here was not protected against oxygen (Fig. 3, after Kaufhold et al., 2015a).

Because of the importance of the metal barrier, bentonite-iron interactions have been studied thoroughly (Lantenois et al., 2005; Xia et al., 2005; Perronnet et al., 2007; Carlson et al., 2007; Osacký et al., 2010). Most of these studies have focused on the type of the corrosion product. Magnetite and neoformed layered silicates such as saponite, berthierine, and/or chlorite have been reported (Gauillaume et al., 2003; Wilson et al., 2006a; Osacky et al., 2010). Most of the studies concluded that a 1:1 Fe layered silicate (berthierine) forms at lower temperatures and a chlorite-type Fe layered silicate prevails at elevated temperature, i.e. $>100^{\circ} \mathrm{C}$ (Wilson et al., 2006b). The role of the bentonite with respect to the corrosion mechanism, however, is not fully understood yet. Kaufhold et al. (2015b) compared 38 different bentonites in five different exposition tests which were performed anaerobically at $60^{\circ} \mathrm{C}$ for 5 months. An iron pellet was cleaned, dried and weighed before and after the exposition tests. The interlayer composition was varied by cation exchange followed by dialysis. The corrosion rates ranged from 2 to $20 \mu \mathrm{m} / \mathrm{a}$. The much smaller rater of corrosion $(0.1 \mu \mathrm{m} / \mathrm{a}$, $)$ reported by Xia et al. (2005) can be explained by different solid/liquid ratios and the extent of the experiments.

Na-rich bentonites were slightly less corrosive than $\mathrm{Ca} / \mathrm{Mg}$-bentonites, but most of the bentonites with low charge were more corrosive (Fig. 4). Some Wyoming bentonites containing low-charged $\mathrm{Na}$-smectites were rather corrosive which suggests that the layer-charge density is more important with respect to the corrosion rate than the type of interlayer cation. Generally, highcharge smectites are less corrosive and hence bentonites containing such smectites should be preferred. In these studies the Fe content of the smectites was not connected to the tendency to corrode. However, to identify a less corrosive and hence more suitable bentonite unambiguously, comparative tests should be performed (e.g. Kaufhold et al., 2015b).

\section{Issue 5 - stability against erosion and detachment of colloidal particles}

Flow of water in contact with the bentonite may detach colloidal smectite particles leading to erosion and hence weakening of the barrier. Detached colloids could also act as a vehicle for radionuclides if they are strongly adsorbed to the colloid surface (Missana et al., 2002; Mayordomo et al., 2016, this volume). The parameters affecting the erosion can be subdivided into those affecting the mechanical erosion and those affecting the colloidal properties of the smectites, which lead to the detachment of colloidal particles out of aggregates. Mechanical erosion can detach entire aggregates because the velocity of the flowing water is large enough to exceed the attractive forces holding bentonite aggregates in place. Therefore, erosion depends on the velocity of the water in the fissure (Pusch, 1999; Birgersson et al., 2009). Recently, Svoboda (2013) found that erosion also depended on the aperture of the fissure. Colloidal detachment, however, may even take place in contact with static water. The detachment of colloidal particles depends on the ionic strength and the $\mathrm{pH}$ of the surrounding solution (Missana et al., 2003). Those parameters affect the extent of the diffuse double layer and hence the interaction of the particles. A low affinity of smectite TOT-layers towards each other can lead to delamination and hence detachment of colloidal particles. Kaufhold \& Dohrmann (2008) compared different bentonites with respect to the tendency to release colloidal particles in dilute systems of low ionic strength (Fig. 5).

Na-rich bentonites released far more colloidal particles than $\mathrm{Ca} / \mathrm{Mg}$-rich bentonites because of different hydration characteristics. With excess water $\mathrm{Na}$-smectites tended towards infinite swelling which allows delamination and hence detachment of colloidal particles (e.g. Suquet et al., 1975). Increased salinity and/or exchange of $\mathrm{Na}^{+}$by $\mathrm{Ca}^{2+} / \mathrm{Mg}^{2+}$ from solution generally reduces the probability of detachment of colloidal particles. No effect of the layer-charge density of the smectites was observed. This issue is only relevant if flowing water is present in contact with the bentonite. Therefore, no general recommendation can be given. Recent up-scale tests showed quick equilibration of the interlayer cation population with 

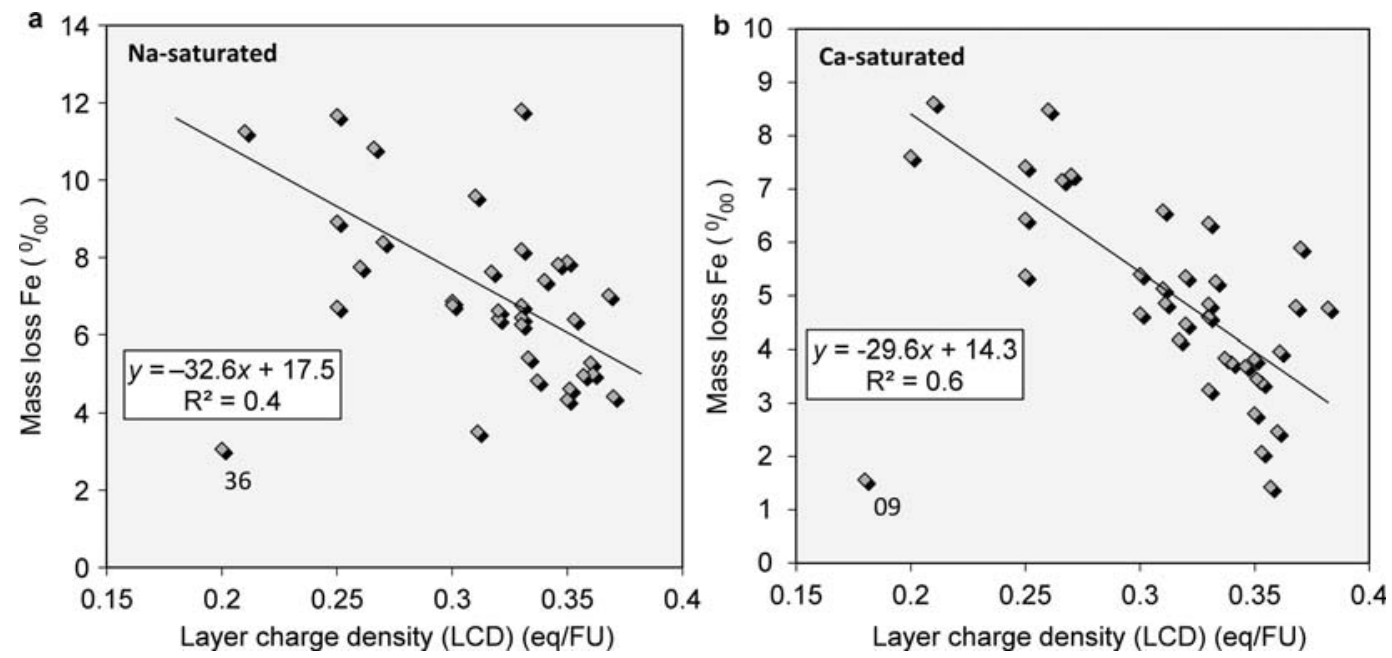

FIG. 4. Effect of smectite layer-charge density on the corrosion at the bentonite-iron interface (after Kaufhold et al., 2015a).

the surrounding water (Dohrmann et al., 2013b) and that the type of interlayer cation initially present is less important (van Geet \& Dorhmann, 2016, this issue).

Issue 6 - stability in the presence of $\mathrm{Na}$ - and $\mathrm{KCl}$-solutions

Intensive work has been carried out on the stability of bentonites in contact with different solutions. Particular focus has been placed on specific reactions leading to decreasing swelling capacity. The first reaction to consider is cation exchange. The interlayer composition (type and amount of exchangeable cations) will soon re-equilibrate if bentonite is in contact with saline waters. Such cation exchange processes are surprisingly fast, even in highly compacted bentonite blocks (Dohrmann et al., 2013b). Cation exchange may affect physico-chemical and geotechnical properties such as swelling or hydraulic conductivity. These changes are reversible and hence do not represent a serious threat to the barrier system. At temperatures of $>100^{\circ} \mathrm{C}$, however, hydrothermal reactions may alter the bentonites irreversibly (Pusch et al., 1995) probably by dissolution of smectites and precipitation of non-swelling minerals. Reduction of the smectite content generally leads to

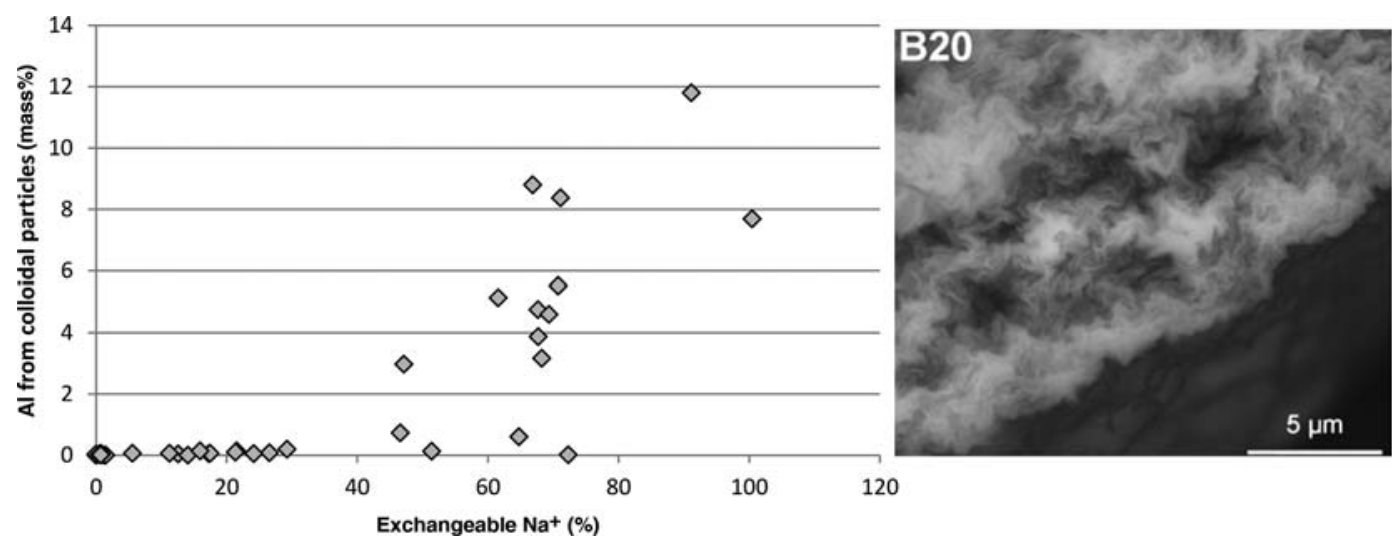

FIG. 5. Comparison of the amount of exchangeable $\mathrm{Na}^{+}$with aqueous $\mathrm{Al}^{3+}$ used as a measure of the concentration of colloidal particles in suspension. The colloidal particles belong to smectitic layers (after Kaufhold \& Dohrmann, 2008). 
lower swelling and hence lower sealing capacity. Suzuki et al. (2008) reported irreversible changes (reduction of CEC and precipitation of brucite) at $90^{\circ}$ C. The reactivity of the bentonites in this respect is variable and probably depends on the chemical stability of different smectites. To investigate the influence of different, smectites, Kaufhold \& Dohrmann (2009) reacted a set of different, well characterized bentonites with a $6 \mathrm{M} \mathrm{NaCl}$ solution at $60^{\circ} \mathrm{C}$ for 5 months. As expected, exchange of $\mathrm{Ca}^{2+}$ and/or $\mathrm{Mg}^{2+}$ for $\mathrm{Na}^{+}$was observed. The extent to which the cation exchange occurred depended on carbonate abundance. Bentonites containing at least partly soluble carbonates (e.g. calcite) contained less exchangeable $\mathrm{Na}^{+}$after the long-term test than their carbonate-free counterparts, suggesting that the presence of carbonates buffers cation exchange reactions to some extent.

The similar CEC values before and after the $\mathrm{NaCl}$ long-term test indicates the absence of irreversible mineral alteration reactions (Fig. 6). After a similar test conducted with $\mathrm{KCl}$, however, an average decrease in the CEC values of $\sim 10 \%$ was recorded (Kaufhold \& Dohrmann, 2010b; Fig. 6).

Unlike $\mathrm{Na}^{+}, \mathrm{K}^{+}$may be fixed by smectite, finally resulting in illite-like layers. Due to the importance of the illitzation of smectite for the oil industry, a vast amount of data on illitization is available (e.g. Hower et al., 1976; Boles \& Franks, 1979; Eberl et al., 1986; Eberl et al., 1993; Bauer \& Velde, 1999; Mosser-Ruck et al., 2001; Meunier \& Velde, 2004; Honty et al., 2004; Kaufhold \& Dohrmann, 2010b, among many others). These studies suggest that the addition of $\mathrm{K}^{+}$to smectite may cause illitization. The mechanism of illitization, however, is still under discussion, and both solid-state transformation and dissolution (of smectite) and precipitation (of illite) have been considered. According to Kaufhold \& Dohrmann (2010b), care is needed with respect to interpretation of experimental illitization tests because the appearance of a $10 \AA$ diffraction maximum is not sufficient to identify illite sensu stricto. Those authors concluded that a multimethod approach is required for the characterization of the $\mathrm{KCl}$ reaction products because of the existence of non-swelling clay minerals with CEC. Illitization may occur if $\mathrm{K}$ is available in the system because smectite becomes unstable in the presence of $\mathrm{K}$ and illite forms, probably mainly by dissolution/precipitation. Based on long-term tests, Kaufhold \& Dohrmann (2010b) identified differences in the reactivity of bentonites with respect to illitization. Similar to the drying experiments (issue 2) the batch experiments showed that the CEC of some bentonites decreased more, and hence they were more reactive than others. The reason for these differences, however, is not understood yet.

\section{Issue 7 - retention of radionuclides}

An additional desired property of the bentonite is the capacity to adsorb radionuclides released by the HLRW in the canister. If the canister fails, different species of radionuclides would enter the bentonite, which might be adsorbed at the mineral surfaces and hence might be retained. However, a large number of different radionuclides must be considered. The interaction of smectites with different radionuclides has been studied extensively $\left({ }^{60} \mathrm{Co}\right.$ : Omar et al., 2009; ${ }^{241}$ Am: Basuki \& Muzakky, 2010; ${ }^{137}$ Cs: Basuki \& Muzakky, 2010; Kerisit et al., 2016; Seliman et al., 2014; Eu: Seliman et al., 2014; ${ }^{90}$ Sr: Basuki \& Muzakky, 2010; Seliman et al., 2014; ${ }^{99}$ Tc: Dejun et al., 2004; U: Bachmaf et al., 2008, Khalili et al., 2013; Th: Khalili et al., 2013). Depending on the different charge densities/charge distributions and/or chemical compositions of the smectites, the bentonites are supposed to differ with respect to their adsorption selectivities (Tournassat et al., 2016). Therefore, it is difficult to decide if the bentonite with greater selectivity towards, e.g. a special uranium species, or that with a slightly greater selectivity towards, e.g. cesium, is more suitable as a HLRW bentonite. Moreover, the differences are small. To assess whether one bentonite is superior to another with respect to radionuclide retention, a ranking of the danger of the different radionuclides would need to be established. However, Oscarson et al. (1986) stressed the importance of ${ }^{129} \mathrm{I}$ amongst all other radionuclides. Iodide, however, would not be retained by a normal bentonite. To improve the affinity of a bentonite towards anions, the surface would have to be modified. Bors et al. (2000) suggested the use of organophilic bentonite for iodide retention. This idea was developed further (Dultz \& Bors, 2005; Riebe et al., 2005; Kaufhold et al., 2007). On the other hand, organic matter would be introduced into the system. Several studies have been carried out on the interaction of different radionuclides with modified bentonites (e.g. Simsek \& Ulusoy, 2012; Majdan et al., 2010) suggesting that the affinity of the bentonite towards a specific radionuclide may be modified. The slightly different radionuclide adsorption of the different bentonites is less important and hence plays a minor role with respect to the selection of an ideal HLRW bentonite. 


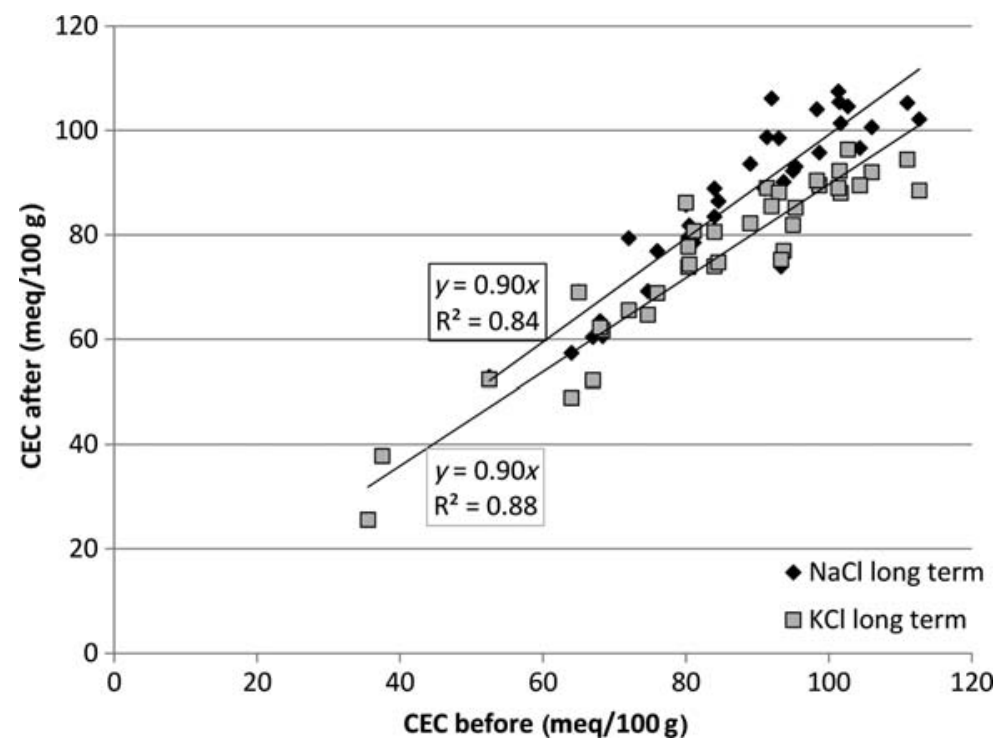

FIG. 6. Comparison of the $\mathrm{CEC}$ before and after long-term reaction with $\mathrm{NaCl}$ (diamonds) and $\mathrm{KCl}$ (squares) at $60^{\circ} \mathrm{C}$ for 5 months (reproduced from Kaufhold \& Dohrmann, 2009, 2010b, with the permission of Elsevier).

Issue 8 - mechanical stability (canister displacement)

The entire integrity of the multi-barrier system can only be guaranteed if all components remain intact. A theoretical earthquake might cause severe damage to the multi-component system and change the relative arrangement of the barrier components. However, details of such a scenario are difficult to predict, even after modelling. In the case of displacement occurring, large swelling pressure will facilitate the sealing of the voids generated. Apart from the earthquake issue, the canister could sink into the bentonite because of the plasticity of the bentonite. According to Sellin \& Leupin (2014) a minimum swelling pressure of $0.1 \mathrm{MPa}$ is sufficient to keep the canister in place and minimize friction. This issue, therefore, is not considered to be important, mainly because the desired swelling pressure should be much larger than $0.1 \mathrm{MPa}$ in any case. Note that, because of the danger of damaging the canister, the swelling pressure should not exceed a critical value which depends on the host rock and the barrier concept. An ideal bentonite should hence provide a swelling pressure between the minimum and maximum values over a large range of dry densities. These requirements, however, vary from one concept to another and, hence, cannot be applied generally. As noted previoulsy, the swelling pressure of a specific bentonite can be tailored by the compaction and, to a much lesser extent, depends on the type of bentonite. An additional parameter which could be considered in this respect is the shear strength (Börgesson et al., 2010; Dueck et al., 2010) which depends significantly on the compaction but may also differ from one bentonite to another. The mechanical properties can be tailored by compaction and hence no bentonite specifications can be derived from issue 8 .

\section{Issue 9 - large thermal conductivity}

Thermal conductivity should be as high as possible, because the heat emitted by the canister should dissipate from the system. The thermal conductivity of bentonite depends mainly on the porosity and degree of water saturation rather than the mineralogical composition. Air-filled porosity is a thermal insulator and water has a much larger thermal conductivity. Varying both parameters in a bentonite, Hökmark (2002) reported a linear relation between thermal conductivity and the degree of saturation with a thermal conductivity of $1 \mathrm{~W} / \mathrm{m} / \mathrm{K}$ at $60 \%$ saturation. For bentonites, typical values of $\sim 1 \mathrm{~W} / \mathrm{m} / \mathrm{K}$ were reported and different reasons for the observed variability were proposed such as water content and relation to bedding (Schärli et al., 2004), water content and ambient pressure (Knutsson, 1983), degree of saturation (Villar, 2002) and particle-particle contacts (Plötze et al., 2007). 
The effect of the type of bentonite on the thermal conductivity is determined by the quartz content which has a significantly larger thermal conductivity than the other components (Clauser \& Huenges, 1995). At a given degree of water saturation the thermal conductivity of a quartz-rich bentonite is larger than materials with less quartz. Therefore, to improve the thermal conductivity in some concepts, quartz is added to the bentonite (Jobmann \& Buntebarth, 2009). For real applications, mixing quartz and bentonite is not feasible because several low-grade bentonite deposits exist, in which $50 \%$ smectite occurs along with $50 \%$ accessory minerals, mainly quartz. In conclusion, for the selection of a highly thermally conducting bentonite, a large quartz content is desirable. However, as the abundance of non-swelling, relatively inert quartz increases, other desired properties deteriorate (e.g. swelling pressure). The thermal conductivity of normal bentonites with quartz contents of $<20$ mass $\%$ depends mainly on the compaction and hence more on the production than on the type of material. A further alternative would be to select a smectite-rich material and add e.g. graphite, as suggested by Pacovsky et al. (2007) and Vašíèek (2007). However, in this case an additional component is introduced to the system which may produce gas (species depends on availability of $\mathrm{O}_{2}$ ) or participate in mineral alteration reactions or even corrosion. The differences in the thermal conductivity of different bentonites depend on the quartz content. The thermal conductivity of highgrade (low-quartz) bentonites depends more on water content and dry density than on the type of bentonite. No generally valid specifications can therefore be derived from issue 9 .

\section{Issue 10 - stability against radiation}

Few studies in the past have investigated the possible degrading effect of radioactivity on the structure of the bentonite. The applied dose is very significant and has to be considered when comparing the published results. Irradiation with 1.1 MGy $\gamma$ radiation increased the number of point defects but did not affect the geotechnical properties (Plötze \& Kahr, 2002; Plötze et al., 2003). These results are in agreement with those of Sorieul et al. (2002) who applied 100 MGy $\beta$ radiation. Sorieul et al. (2008) showed that high temperature $\left(300-400^{\circ} \mathrm{C}\right)$ in combination with large irradiation dosages may lead to partial amorphization. The expected dose for serious structural damage is too low (Pusch et al., 1993; Sellin \& Leupin, 2014). To affect the bentonite seriously, $\alpha$ radiation has to be in direct contact with the bentonite because of the limited penetration depth of the $\alpha$ nuclei. Fourdrin et al. (2010) applied a 73 MGy (dose significantly larger than that expected in the repository) to a bentonite (direct contact) and observed serious structural damage. Structural Fe may play a special role with respect to radiation effects and may, at least, be reduced (e.g. ferric to ferrous iron, Plötze et al., 2003; Sorieul et al., 2008). In summary, the data published to date suggest that the effect of radioactivity on the bentonite will be relevant only in a worst-case scenario (Fourdrin et al., 2010) and that structural Fe may be more prone to radioactivityinduced changes than other structural cations.

\section{DISCUSSION AND CONCLUSIONS}

The aim of the present study was to identify favourable and unfavourable properties of bentonites in HLRW repositories. The bentonite requirements differ significantly from one concept to another which concerns geotechnical parameters such as minimum and maximum swelling pressure or thermal conductivity in particular. From an engineering point of view the compaction of the bentonite can be used to tailor the bentonite performance. In contrast, especially considering the stability of the bentonite, a few aspects were identified allowing for preliminary discussion of potential HLRW specifications.

Similar to the commonly used landfill bentonites, the ideal HLRW bentonite should contain only a few soluble/partly soluble components such as halite and gypsum because their dissolution may change the dry density locally and participate in other reactions (e.g. redistribution of gypsum) which would not occur if they were absent (Karnland et al., 2009). Similar reactions could occur for less soluble but not unreactive phases such as cristobalite, zeolites, amorphous silica, and eventually iron oxyhydroxides. Furthermore, sulfur, either from the surrounding water or from gypsum or pyrite dissolution, might participate in the corrosion of $\mathrm{Cu}$ (Karnland et al., 2009), and pyrite oxidation may lead to $\mathrm{H}_{2} \mathrm{~S}$ formation and increase microbial feed as well as the gas pressure. Hence, the gypsum and pyrite contents should be as small as possible. The presence of minor calcite is less serious because it is scarcely involved in redoxreactions. Calcite could even buffer cation exchange reactions (Kaufhold \& Dohrmann, 2009) which in turn would reduce the risk of erosion. Organic matter should also be absent because it supports microbial growth and produces gas upon decomposition. Notably, the absence of the above-mentioned comparably 
reactive minor constituents possibly present is one of the key specifications of bentonites used for the production of geosynthetic clay liners used in landfills.

Secondly, the hydraulic conductivity should be as low as possible. Despite existing differences in terms of the hydraulic conductivity of different bentonites it can be tailored by compaction, which in turn affects the swelling pressure. Hence the hydraulic conductivity/ swelling pressure of a given bentonite can be adjusted to the desired values. Nevertheless, rather different dry density/swelling pressure/hydraulic conductivity relations were observed. The most suitable materials would be those with least dependence of hydraulic conductivity and swelling pressure on the dry density. However, comparative studies allowing for the selection of the least sensitive bentonites in this respect have yet to be carried out.

At low dry densities, the swelling pressure of Na-rich bentonites is larger but this can be compensated by compaction (Pusch et al., 1995). Otherwise, $\mathrm{Ca}(\mathrm{Mg})$ as the dominant exchangeable cation has some advantages over $\mathrm{Na}$. It buffers alkaline $\mathrm{pH}$ values more effectively than Na-rich bentonites, which is relevant for the cement plug interface. In addition, Ca-rich bentonites do not tend to release colloidal particles as Na-bentonites do. Furthermore, the larger selectivity of $\mathrm{Ca}(\mathrm{Mg})$ towards the interlayer and the fact that most host-rock waters do contain some $\mathrm{Ca}$ will cause fast cation exchange if Na-bentonites are contacted with such solutions (Kaufhold et al., 2013; Dohrmann et al., 2013b). A general recommendation of the type of exchangeable cation initially present may be redundant because of the fast equilibration of the bentonite with the surrounding water. Depending on the barrier concept and particularly on the amount of rock water in contact with the bentonite barrier, the selection of the type of exchangeable cation is only relevant for the early phase of the buffer. In the Äspö rock laboratory the cation exchange (equilibration with rock fluids) was fast (Dohrmann et al., 2013b) so that the cation initially present was less important than the composition of the host-rock water. The pH-buffering effect discussed above, however, is also more important in the early stages of the barrier because of the particularly high $\mathrm{pH}$ of the cement fluids at the beginning. Again, the specific requirements of specific repositories have to be taken into account and a general statement cannot be given.

With respect to Fe corrosion, medium-high-charged bentonites should be preferred (Kaufhold et al., 2015a). Finally, structural Fe can be considered to be a weak point in the smectite structure. The Fe can be reduced either by microbial activity or even by radioactive radiation, thereby increasing its solubility. Ferric iron can also contribute to corrosion because it is an electron acceptor and the thermal stability of bentonites rich in structural $\mathrm{Fe}$ is lower.

In summary, the ideal HLRW bentonite should: be almost free of soluble or reactive (mainly C- and S-) phases such as gypsum, pyrite, organic matter; be low in structural $\mathrm{Fe}$; and contain medium-high-charged smectites if iron canisters are used.

The importance of each specification varies from one concept or repository to another. Therefore, each of the key issues has to be assessed individually and no general ranking of the relative importance can be given. Using bentonites other than suggested does not mean that a repository may not be safe. However, using a bentonite within the above-stated specifications reduces the overall uncertainty and hence results in improved long-term barrier performance.

The preliminary specifications presented above are expected to be complemented by additional specifications depending on the results of ongoing research and have to be proven in large-scale experiments in the host rocks to be used. As explained above, the identification of bentonites with low dependency of swelling pressure/hydraulic conductivity on the dry density would improve the barrier performance. In this respect, additional research is needed to complement the specifications listed above. Of further scientific interest would be the identification of the reason for different reactivities. In different tests, similar trends towards the tendency to lose or keep the CEC of different bentonites were found. Hence, a bentonite which displayed considerable loss of its CEC after extensive drying also displayed loss of much of its CEC after the reaction with $\mathrm{KCl}$ or $\mathrm{NaCl}$ solutions. Yet no explanation for this trend was found. Explanations could be the solubility of the smectite which depends on the chemical composition, or degree of structural order, probably in combination with particle size. The identification of the reason for these differences would also complement the specifications given above.

Some of the properties-performance relations of bentonites are not yet fully understood. Therefore, using a bentonite which has been investigated extensively over many years is likely to bear less uncertainty compared to unknown materials.

\section{ACKNOWLEDGEMENTS}

The authors thank Patrik Sellin for a detailed discussion and many ideas to improve the manuscript and the two 
reviewers, Sirpa Kumpulainen and Jörn Kasbohm, for many constructive remarks and ideas.

\section{REFERENCES}

Agus S.S. \& Schanz T. (2008) An alternative method for predicting swelling pressure of compacted bentonites. Acta Geotechnica, 3, 125-137.

Bachmaf S., Planer-Friedrich B. \& Merkel B.J. (2008) Uranium sorption and desorption behavior on bentonite. Pp. 515-524 in: Uranium, Mining and Hydrogeology (B.J. Merkel \& A. Hasche-Berger, editors). Springer, Berlin, DOI: 10.1007/978-3-540-87746-2_63.

Basuki K.T. \& Muzakky M. (2010) Adsorption of Am241, Cs-137 and Sr-90 radionuclides with bentonitehumic acid immobilized yield. Indonesian Journal of Chemistry, 10, 1-7.

Bauer A. \& Velde B. (1999) Smectite transformation in high molar $\mathrm{KOH}$ solutions. Clay Minerals, 34, 259-273.

Bauer A., Lanson B., Ferrage E., Emmerich K., Taubald H., Schild D. \& Velde B. (2006) The fate of smectite in $\mathrm{KOH}$ solutions. American Mineralogist, 91, 1313-1322.

Berner U.R. (1992) Evolution of pore water chemistry during degradation of cement in a radioactive waste repository environment. Waste Management, 12, 201-219.

Birgersson M., Börgesson L., Hedström M., Karnland O. \& Nilsson U. (2009) Bentonite erosion. SKB technical report, TR 09-34, Svensk Kärnbränslehantering AB, Stockholm. Available online at: http://www.skb.se/ upload/publications/pdf/TR-09-34.pdf

Börgesson L. \& Hernelind J. (2010) Earth quake induced rock shear through a deposition hole - modelling of three model tests scales 1:10. SKB-TR-10-33, Svensk Kärnbränslehantering $\mathrm{AB}$, Stockholm.

Boles J.R. \& Franks S.G. (1979) Clay diagenesis in Wilcox sandstones of southwest Texas: implications of smectite diagenesis on sandstone cementation. Journal of Sedimentary Petrology, 49, 55-70.

Bors J., Dultz S. \& Riebe B. (2000) Retention of radionuclides by organophilic bentonite. Engineering Geology, 54, 195-206.

Carlson L., Karnland O., Oversby V.M., Rance A.P., Smart N.R., Snellman M., Vähänen M. \& Werme L.O. (2007) Experimental studies of the interactions between anaerobically corroding iron and bentonite. Physics and Chemistry of the Earth, 32, 334-345.

Clauser C. \& Huenges E. (1995) Thermal conductivity of rocks and minerals. Pp. 105-126 in: Rock Physics and Phase Relations - a Handbook of Physical Constants (T.J. Ahrens, editor). AGU Reference Shelf, Vol. 3, American Geophysical Union, Washington DC.

Cuevas J., Fernandez R., Sanchez L., Vigil de la Villa R., Rodriguez M. \& Leguey S. (2007) Reactive diffusion front driven by an alkaline plume in compacted $\mathrm{Mg}$ homoionic bentonite. ANDRA Conference: Clays in Natural \& Engineered Barriers for Radioactive Waste Confinement, International Meeting Lille 2007, available online at: http://www.andra.fr/lille2007/abstract lille2007/donnees/pdf/509_510_P_MTPM_44.pdf

Dejun L., Xianhua F., Yingjie Z., Jun Y., Duo Z. \& Yong W. (2004) Adsorption behavior of 99Tc in Cabentonite. Chinese Journal of Nuclear Science and Engineering, 24, 144-151.

Dohrmann R., Kaufhold S. \& Lundqvist B. (2013a) The role of clays for safe storage of nuclear waste. Pp. 677-710 in: Handbook of Clay Science: Techniques and Applications (F. Bergaya and G. Lagaly, editors). Developments in Clay Science, Vol. 5B, Elsevier, Amsterdam.

Dohrmann R., Olsson S., Kaufhold S. \& Sellin P. (2013b) Mineralogical investigations of the first package of the alternative buffer material test - II. Exchangeable cation population rearrangement. Clay Minerals, $\mathbf{4 8 ,}$ 215-233.

Dueck A., Börgesson L. \& Johannesson L.-E. (2010) Stress-strain relation of bentonite at undrained shear. Laboratory tests to investigate the influence of material composition and test technique. SKB TR-10-32.

Dultz S. \& Bors J. (2005) Organophilic bentonites as adsorbents for radionuclides. II. Chemical and mineralogical properties of HDPy montmorillonite. Applied Clay Science, 16, 15-29.

Eberl D.D., Środoń J. \& Northrop H.R. (1986) Potassium fixation in smectite by wetting and drying. Pp. 296-326 in: Geochemical Processes at Mineral Surfaces (J.A. Davis \& K.F. Hayes, editors). ACS Symposium Series, 323, American Chemical Society.

Eberl D.D., Velde B. \& McCormick T. (1993) Synthesis of illite-smectite from smectite at earth surface temperatures and high pH. Clay Minerals, 28, 49-60.

Fernández R., Rodríguez M., Vigil de la Villa R. \& Cuevas J. (2010) Geochemical constraints on the stability of zeolites and $\mathrm{C}-\mathrm{S}-\mathrm{H}$ in the high $\mathrm{pH}$ reaction of bentonite. Geochimica et Cosmochimica Acta, 74, 890-906.

Fourdrin C., Allard T., Monnet I., Menguy N., Benedetti M. \& Calas A. (2010) Effect of radiation-induced amorphization on smectite dissolution. Environmental Science and Technology, 44, 2509-2514.

Fries T., Claudel A., Weber H., Johnson L. \& Leupin O. (2008) The Swiss concept for the disposal of spent fuel and vitrified HLW. International Conference Underground Disposal Unit Design \& Emplacement Processes for a Deep Geological Repository, 16-18 June 2008, Prague, available online at: http://ibrary. sinap.ac.cn/db/fangshexing201103/\%E5\%85\%A $8 \%$ E6\%96\%87/41025019.pdf

Fru E.C. \& Athar R. (2008) In situ bacterial colonization of compacted bentonite under deep geological highlevel radioactive waste repository conditions. Applied Microbiology and Biotechnology, 79, 499-510. 
Greene-Kelly K. (1953) Irreversible dehydration in montmorillonite, part II. Clay Minerals Bulletin, 2, 52-56.

Hatem M., Pusch R., Warr L. \& Kasbohm J. (2015) Interaction of clay and concrete relevant to the deep disposal of high-level radioactive waste. Applied Clay Science, 118, 178-187.

Hökmark H. (2002) Hydration of the bentonite buffer in a KSB-3 repository. ANDRA: Clays in Natural and Engineered Barriers for Radioactive Waste Confinement. International Meeting, Reims.

Hofmann U. \& Klemen R. (1950) Verlust der Austauschfahigkeit von Lithiumionen an Bentonit durch Erhitzung. Zeitschrift für Anorganische Chemie, 262, 95-99.

Honty M., Uhlík P., Šucha V., Caploviçová M., Franců J., Clauer N. \& Biron A. (2004) Smectite-to-illite alteration in salt-bearing bentonites (the East Slovak basin). Clays and Clay Minerals, 52, 533-551.

Hower J., Eslinger E.V., Hower M.E. \& Perry Jr. E.A. (1976) Mechanism of burial metamorphism of argillaceous sediment, I. Mineralogical and chemical evidence. Geological Society of America Bulletin, 87, $725-737$.

Jobmann M. \& Buntebarth G. (2009) Influence of graphite and quartz addition on the thermo-physical properties of bentonite for sealing heat-generating radioactive waste. Applied Clay Science, 44, 206-210.

Karnland O., Olsson S. \& Nilsson U. (2006) Mineralogy and sealing properties of various bentonites and smectite-rich clay materials. SKB technical report, TR 06-30. Available online at: http://www.skb.se/upload/ publications/pdf/TR-06-30.pdf

Karnland O., Olsson S., Dueck A., Birgersson M., Nilsson U., Hernan-Håkansson T., Pedersen K., Nilsson S., Eriksen T.E. \& Rosborg B. (2009) Long term test of buffer material at the Äspö Hard Rock Laboratory, LOT project - Final report on the A2 test parcel, Technical Report TR-09-29. Available online at: http:// www.skb.se/upload/publications/pdf/TR-09-29.pdf

Kaufhold S. \& Dohrmann R. (2008) Detachment of colloidal particles from bentonites in water. Applied Clay Science, 39, 50-59.

Kaufhold S. \& Dohrmann R. (2009) Stability of bentonites in salt solutions. I. Sodium chloride. Applied Clay Science, 45, 171-177.

Kaufhold S. \& Dohrmann R. (2010a) Effect of extensive drying on the cation exchange capacity of bentonites. Clay Minerals, 45, 441-448.

Kaufhold S. \& Dohrmann R. (2010b) Stability of bentonites in salt solutions. II. Potassium chloride solution - Initial step of illitization? Applied Clay Science, 49, 98-107.

Kaufhold S. \& Dohrmann R. (2011) Stability of bentonites in salt solutions. III. Ca-hydroxide solutions. Applied Clay Science, 51, 300-307.
Kaufhold S., Pohlmann-Lortz M., Dohrmann R. \& Nüesch R. (2007) About the possible upgrade of bentonite with respect to iodide retention capacity. Applied Clay Science, 35, 39-46.

Kaufhold S., Dohrmann R., Koch D. \& Houben G. (2008) The $\mathrm{pH}$ of aqueous bentonite suspensions. Clays and Clay Minerals, 56, 338-343.

Kaufhold S., Dohrmann R., Sandén T., Sellin P. \& Svensson D. (2013) Mineralogical investigations of the alternative buffer material test - I. Alteration of bentonites. Clay Minerals, 48, 199-213.

Kaufhold S., Sanders D., Dohrmann R. \& Hassel A.-W. (2015a) Fe corrosion in contact with bentonites. Journal of Hazardous Materials, 285, 464-473.

Kaufhold S., Baille W., Schanz T. \& Dohrmann R. (2015b) About differences of swelling pressure-dry density relations of compacted bentonites. Applied Clay Science, 107, 52-61.

Khalili F.I., Salameh N.H. \& Shaybe M.M. (2013) Sorption of uranium(VI) and thorium(IV) by Jordanian bentonite. Journal of Chemistry, Article ID 586136, 13 pp. http://dx.doi.org/10.1155/2013/ 586136

Kerisit S., Okumura M., Rosso K.M. \& Machida M. (2016) Molecular simulation of cesium adsorption at the basal surface of phyllosilicate minerals. Clays and Clay Minerals, in press. DOI: 10.1346/ CCMN.2016.0640405.

Knutsson S. (1983) On the thermal conductivity and thermal diffusivity of highly compacted bentonite. SKBF Technical KBS Report 83-72. SKB, Stockholm. Available online at: http:/www.skb.se/ upload/publications/pdf/TR83-72webb.pdf

Komine H. (2004) Simplified evaluation for swelling characteristics of bentonites. Engineering Geology, 71, 265-279.

Lantenois S., Lanson B., Muller F., Bauer A., Jullien M. \& Plançon A. (2005) Experimental study of smectite interaction with metal $\mathrm{Fe}$ at low temperature: 1 . Smectite destabilization. Clays and Clay Minerals, 53, 597-612.

Lee J.O., Cho W.J., Kang C.H. \& Chun K.S. (1999) Swelling and hydraulic properties of Ca-bentonite for the buffer of a waste repository. The International Symposium on Technologies for the Management of Radioactive Waste from Nuclear Power Plants and Back End Nuclear Fuel Cycle Activities, September 1999, available online at: http://www-pub.iaea.org/ MTCD/publications/PDF/csp_006c/PDF-Files/paper68.pdf

Majdan M., Pikus S., Gajowiak A., Sternik D. \& Zieba E. (2010) Uranium sorption on bentonite modified by octadecyltrimethylammonium bromide. Journal of Hazardous Materials, 184, 662-670.

Mayordomo N., Degueldre C. Alonso U. \& Missana T. (2016) Size distribution of FEBEX bentonite colloids 
upon fast disaggregation in low ionic strength water. Clay Minerals, 51, 213-222.

Missana T., Garcia-Gutiérrez M. \& Alonso U. (2002) Kinetics and irreversibility of cesium and uranium sorption onto bentonite colloids. ANDRA: Clays in Natural and Engineered Barriers for Radioactive Waste Confinement, Reims, 2002, Program and Abstracts.

Missana T., Alonso U. \& Turrero M.J. (2003) Generation and stability of bentonite colloids at the bentonite/ granite interface of a deep geological radioactive waste repository. Journal of Contaminant Hydrology, 61, 17-31.

Meunier A. \& Velde B. (2004) Illite: Origins, Evolution, and Metamorphism. Springer, Berlin, $286 \mathrm{pp}$.

Mosser-Ruck R., Pironon J., Cathelineau M. \& Trouiller A. (2001) Experimental illitization of smectite in a Krich solution. European Journal of Mineralogy, 13, 829-840.

NAGRA (1995) Column experiments: results of experiments and modelling. NAGRA NTB, Report 95-70, Baden, Switzerland.

Omar H., Arida H. \& Daifullah A. (2009) Adsorption of 60 Co radionuclides from aqueous solution by raw and modified bentonite. Applied Clay Science, 44, 21-26.

Osacký M., Šucha V.A., Czímerová A. \& Madejová J. (2010) Reaction of smectites with iron in a nitrogen atmosphere at $75^{\circ} \mathrm{C}$. Applied Clay Science, 50, 237-244.

Oscarson D.W., Miller H.G. \& Watson R.L. (1986) An evaluation of potential additives to a clay-based buffer material for the immobilization of I-129. AECL Report 9068. Atomic Energy of Canada Limited, Pinawa, Canada, 24 pp.

Pacovsky J., Svoboda J. \& Zapletal L. (2007) Saturation development in the bentonite barrier of the mock-up$\mathrm{CZ}$ geotechnical experiment. Physics and Chemistry of the Earth, 32, 767-779.

Perronnet M., Villiéras F., Jullien M., Razafitianamaharavo A., Raynal J. \& Bonnin D. (2007) Towards a link between the energetic heterogeneities of the edge faces of smectites and their stability in the context of metallic corrosion. Geochimica et Cosmochimica Acta, 71, 1463-1479.

Plötze M. \& Kahr G. (2002) Alteration of clay mineralsirradiation effects on physicochemical properties. Workshop on Clay microstructure and its importance to soil behaviour, SKB, Lund.

Plötze M., Kahr, G. \& Stengele R.H. (2003) Alteration of clay minerals - gamma-irradiation effects on physicochemical properties. Applied Clay Science, 23, 195-202.

Plötze M., Schärli U., Koch A. \& Weber H. (2007) Thermophysical properties of compacted bentonite. Clays in Natural \& Engineered Barriers for radioactive waste confinement. International meeting, ANDRA, Lille, France.
Pusch R. (1999) Clay colloid formation and release from MX-80 buffer. SKB Technical Report No: TR-99-31, Stockholm.

Pusch R., Karnland O., Lajudie A. \& Decarreau A. (1993) $M X-80$ exposed to high temperatures and gamma radiation. SKB-TR 93-03, Stockholm.

Pusch R., Börgesson L., Fredriksson A., Johannesson L.-E., Hökmark H., Karnland O. \& Sandén T. (1995) The Buffer and Backfill Handbook. Technical Report 95-45, SKB, Clay Technology AB, Sweden.

Pusch R., Kasbohm J. \& Thao H.T.M. (2010) Chemical stability of montmorillonite buffer clay under repository-like conditions - A synthesis of relevant experimental data. Applied Clay Science, 47, 113-119.

Ramirez S., Cuevas J., Vigil R. \& Leguey S. (2002) Hydrothermal alteration of "La Serrata" bentonite (Almeria, Spain) by alkaline solutions. Applied Clay Science, 21, 257-269.

Riebe B., Dultz S. \& Bunnenberg C. (2005) Temperature effects on iodine adsorption on organo-clay minerals. I. Influence of pretreatment and adsorption temperature. Applied Clay Science, 28, 9-16.

Savage D. \& Benbow S. (2007) Low-pH Cements. SKI Report 2007:32, available online at: http://www. stralsakerhetsmyndigheten.se/Global/Publikationer/ SKI_import/070910/3cb586183d14168b8ae47845c 82ae00b/web\%202007_32.pdf

Savage D., Benbow S., Watson C., Takase H., Ono K., Oda C. \& Honda A. (2010) Natural systems evidence for the alteration of clay under alkaline conditions: An example from Searles Lake, California. Applied Clay Science, 47, 72-81.

Sellin P. \& Leupin O. (2014) The use of clay as an engineered barrier in radioactive waste management a review. Clays and Clay Minerals, 61, 477-498.

Schärli U., Plötze M. \& Kahr G. (2004) Thermische Messungen an Bentonit. Berichte der DTTG, 10, $80 \mathrm{pp}$.

Seliman A.F., Lasheen Y.F., Youssief M.A.E., Abo-Aly M.M. \& Shehata F.A. (2014) Removal of some radionuclides from contaminated solution using natural clay: bentonite. Journal of Radioanalytical and Nuclear Chemistry, 300, 969-979.

Simsek S. \& Ulusoy U. (2012) Uranium and lead adsorption onto bentonite and zeolite modified with polyacrylamidoxime. Journal of Radioanalytical and Nuclear Chemistry, 292, 41-51.

SKB (2010) Design and production of the KBS-3 repository. Technical report TR-10-12, Svensk Kärnbränslehantering $\mathrm{AB}$, Stockholm, available online at: http://www.skb.se/upload/publications/pdf/ TR-10-12.pdf

Sorieul S., Allard Th., Boizot B., Chaumont J. \& Calas G. (2002) Ionization-Radiation effects in montmorillonite. ANDRA: Clays in Natural and Engineered 
Barriers for Radioactive Waste Confinement. International Meeting, Reims, Frances.

Sorieul S., Allard Th., Wang L.M., Gramblin-Lapeyre C., Lian J., Calas G. \& Ewing R.C. (2008) Radiationstability of smectite. Environmental Science \& Technology, 42, 8407-8411.

Suquet H., de la Calle C. \& Pezzerat H. (1975) Swelling and structural organization of saponite. Clays and Clay Minerals, 23, 1-9.

Suzuki S., Sazarashi M., Akimoto T., Haginuma M. \& Suzuki K. (2008) A study of the mineralogical alteration of bentonites in saline water. Applied Clay Science, 41, 190-198.

Svoboda J. (2013) The experimental study of bentonite swelling into fissures. Clay Minerals, 48, 383-389.

Tournassat C., Bourg I.C., Holmboe M., Sposito G. \& Steefel C.I. (2016) Molecular dynamics simulations of anion exclusion in clay interlayer nanopores. Clays and Clay Minerals, in press. DOI: 10.1346/ CCMN.2016.0640403.

van Geet M. \& Dohrmann R. (2016) Overview of the clay mineralogy studies presented at the "Clays in natural and engineered barriers for radioactive waste confinement' meeting, Brussels. Clay Minerals, 51, $125-128$.
Vašíèek R. (2007) Mock-up-CZ Experiment. CTU Prague, Faculty of Civil Engineering, http://ceg.fsv.cvut.cz/ EN/ceg-downloads

Villar M.V. (2002) Thermo-hydro-mechanical characterisation of a bentonite from Cabo de Gata: A study applied to the use of bentonite as a sealing material in high level radioactive waste repositories. $\mathrm{PhD}$ thesis, Universidad Complutense de Madrid, Facultad de Ciencias Geológicas, Departamento de Geodinámica. ENRESA Publicación técnica 04/2002. ISSN: 1134380X, Spain.

Wilson J., Savage D., Cuadros J., Shibata M. \& Ragnarsdottir K.V. (2006a) The effect of iron on montmorillonite stability. (I) Background and thermodynamic considerations. Geochimica et Cosmochimica Acta, 70, 306-322.

Wilson J., Cressey G., Cressey B., Cuadros J., Ragnarsdottir K.V., Savage D. \& Shibata M. (2006b) The effect of iron on montmorillonite stability. (II) Experimental investigation. Geochimica et Cosmochimica Acta, 70, 323-336.

Xia X., Idemitsu K., Arima T., Inagaki Y., Ishidera T., Kurosawa S., Iijima K. \& Sato H. (2005) Corrosion of carbon steel in compacted bentonite and its effect. Applied Clay Science, 28, 89-100. 